\title{
Komunikasi Retorika oleh Brand Ambassador dalam Kampanye Kosmetik Cruelty-Free
}

\author{
${ }^{1}$ Monica Aprillia Gunti Saputri, ${ }^{2}$ Indra Novianto Adibayu Pamungkas, SS., M.Si \\ ${ }^{1,2}$ Program Studi S1 Ilmu Komunikasi, Fakultas Komunikasi dan Bisnis, Telkom University \\ 1 mail.aprilliamonica@gmail.com, 2 indra.imi28@gmail.com
}

\begin{abstract}
ABSTRAK
Sebelum sebuah produk kosmetik siap dipasarkan, produk tersebut harus mengalami pengujian terlebih dahulu. Pengujian ini biasanya dilakukan terhadap binatang, khususnya kelinci putih. Tidak jarang binatang-binatang tersebut teracuni, buta, bahkan mati akibat pengujian ini. Pengujian terhadap binatang atau animal testing adalah salah satu bentuk dari penyiksaan terhadap binatang atau animal abuse. Hal ini lah yang ditentang oleh The Body Shop sejak pertama berdiri pada 1976, merek ini berkomitmen untuk menjadi merek kosmetik cruelty-free, merek yang tidak melakukan pengujian terhadap binatang. Di pasar Indonesia, The Body Shop sudah hadir sejak tahun 1992 dan baru pada tahun 2017 memiliki seorang Brand Ambassador, yaitu Cinta Laura. Penelitian ini bertujuan untuk mencari tahu bagaimana komunikasi retorika Cinta Laura sebagai Brand Ambassador kosmetik crueltyfree. Penelitian ini merupakan penelitian kualitatif dengan paradigma konstruktivisme, serta menggunakan metode deskriptif. Teknik pengumpulan data yang digunakan adalah wawancara mendalam dengan tiga jenis informan, yaitu informan kunci, informan ahli, dan juga informan pendukung. Dari penelitian ini dapat diperoleh hasil bahwa komunikasi retorika yang dilakukan oleh Cinta Laura sebagai brand ambassador dari The Body Shop Indonesia yang mengkampanyekan kosmetik cruelty-free sudah sesuai arahan yang diberikan oleh pihak perusahaan. Namun, audience melihat komunikasi retorika yang ia lakukan lebih fokus pada agenda untuk meningkatkan penjualan saja, dan kurang meyakinkan audience dalam hal kampanye yang dibawakan.
\end{abstract}

Kata kunci: komunikasi retorika, brand ambassador, post-truth, cruelty-free, The Body Shop

\section{ABSTRACT}

Before cosmetics products are ready to be marketed, they have to be tested first. The test is usually done to animals, especially white rabbits. Often these animals are poisoned, blind, even dead due to this test. Animal testing is a form of animal abuse. This is what The Body Shop is against ever since it started back in 1976, this brand is committed to become a cruelty-free cosmetics brand, which do not do any form of animal abuse. In the Indonesian market, The Body Shop has been here since 1992, and only in 2017 has it announced its first 
brand ambassador - a celebrity named Cinta Laura. The purpose of this research is to find out about her rhetoric communication as a brand ambassador of a cruelty-free cosmetics brand. This is a qualitative research with constructivism paradigm, using descriptive method. Data collection technique used is in-depth interview with three types of informants - key, expert, and supporting. From this research, we know that Cinta Laura's rhetoric communication as The Body Shop Indonesia's brand ambassador is already as the company instructed her. But, the audience sees it's more focused on increasing sales and not convincing enough in terms of the campaign.

Keywords: rhetoric communication, brand ambassador, cruelty-free, The Body Shop

\section{PENDAHULUAN}

DeVito menjelaskan bahwa komunikasi mengacu pada tindakan satu orang atau lebih yang mengirim dan menerima pesan yang terdistorsi oleh gangguan, yang terjadi dalam konteks tertentu, mempunyai pengaruh tertentu, dan kesempatan untuk melakukan umpan balik (dalam Meidiawati, 2015). Effendy mengungkapkan beberapa tujuan komunikasi, yaitu untuk mengubah sikap (to change the attitude), mengubah opini (to change the opinion), mengubah perilaku (to change the behaviour), dan mengubah masyarakat (to change the society) (dalam Meidiawati, 2015).

Dalam menyampaikan pesan kepada audiencenya, sebuah merek sering menggunakan brand ambassador sebagai komunikator. Pemaparan Keith mengenai brand ambassadors adalah individu yang memiliki pengetahuan mengenai perusahaan dan mereka juga memiliki kemampuan untuk mengkomunikasikan nilai merek perusahaan kepada para pelanggan (dalam Aulia, 2018). Ted Wright mengidentifikasi brand ambassador sebagai orang-orang pemberi pengaruh, mereka lah yang selalu punya rekomendasi terbaik tentang apapun yang mereka minati. Mereka juga memiliki banyak informasi yang bernilai untuk orang-orang sekitarnya. Lebih lanjut, Wright mengemukakan bahwa influencer (pemberi pengaruh) adalah sebuah personality (kepribadian) bukan seseorang (dalam Funk, 2012).

Wheeler (2009) mengungkapkan bahwa brand memiliki tiga fungsi, yaitu navigation, engagement, dan reassuramce. Fungsi navigation menjelaskan bahwa brand membantu konsumen dalam memilih produk saat dihadapi oleh pilihan yang membingungkan. Fungsi engagement menjelaskan bahwa dengan adanya ciri khas, bahasa, serta asosiasi-asosiasi yang muncul antara konsumen dengan produk yang ditawarkan dapat mendorong konsumen untuk membedakan brand tertentu dengan pesaingnya. Fungsi reassurance menjelaskan bahwa brand membantu mengkomunikasikan informasi terkait unsur intrinsik dan juga kualitas produk maupun jasa, sehingga meyakinkan konsumen bahwa apa yang mereka pilih merupakan pilihan yang tepat (dalam Ansellina, 2015).

Pengujian produk kosmetik terhadap binatang merupakan bentuk animal abuse yang banyak dikecam oleh masyarakat di seluruh dunia. Dengan kecaman atas praktik animal abuse dalam pengujian terhadap binatang yang dilakukan oleh merek-merek kosmetik, dalam konteks ini The Body Shop hadir dan memenuhi fungsi reassurancenya sebagai sebuah brand. Dimana The Body Shop memberi rasa aman dan yakin kepada para konsumennya, bahwa yang mereka pilih adalah pilihan yang tepat. Sebuah produk kosmetik akan disebut cruelty-free bila dalam sepanjang proses produksinya tidak melakukan pengujian terhadap binatang. Untuk mengetahui apabila sebuah brand merupakan crueltyfree, sudah ada beberapa lembaga mampu memberi sertifikasi pada merek-merek yang 
memenuhi kriteria kosmetik cruelty-free. The Body Shop sendiri sudah memiliki dua sertifikasi tersebut, yaitu Leaping Bunny dan Cruelty Free dari PETA.

Di Indonesia sendiri, sudah ada beberapa merek kosmetik cruelty-free yang dipasarkan. Namun, sejauh ini The Body Shop masih menjadi merek kosmetik cruelty-free tertua di dunia dan yang pertama hadir di Indonesia, serta memiliki dua sertifikasi crueltyfree. The Body Shop sudah hadir di Indonesia pertama kali pada tahun 1992, dan pada tahun 2017 merek tersebut menunjuk brand ambassador pertamanya, yaitu Cinta Laura. Cinta Laura sendiri merupakan seorang selebriti yang di kenal di kancah nasional dan Internasional sebagai seorang penyanyi dan aktris.

Penelitian ini bertujuan untuk mengetahui komunikasi retorika Cinta Laura sebagai brand ambassador The Body Shop Indonesia dalam menyampaikan kampanye kosmetik cruelty-free.

Dalam penelitian ini, secara garis besar ada dua teori yang digunakan, yaitu teori komunikasi retorika, dan teori brand ambassador. Aristoteles melihat fungsi retorika sebagai penemuan sebuah sarana persuasi. Aristoteles melihat retorika sebagai cabang dari dialektik. Dialektik adalah diskusi one-on-one, dan retorika adalah satu orang yang berbicara kepada banyak orang (dalam Griffin, 1991). Komunikasi retorika fokus pada beberapa hal, yaitu logos, ethos, pathos, dan five canons of rhetoric.

(a) Logos merujuk pada jalan berpikir yang logis. Aristoteles fokus pada dua wujud logos, yaitu entimem dan contoh. Ia merujuk entimem sebagai "bukti terkuat".

Sebuah entimem hanyalah sebuah versi tidak lengkap dari silogisme deduktif formal. Untuk menggambarkan, orang-orang logis dapat membuat silogisme dari yang disampaikan Martin Luther King

(1) Premis mayor: Semua orang diciptakan setara

(2) Premis minor: Saya adalah seseorang

(3) Kesimpulan: Saya setara dengan orang lain

Karena mereka dihasilkan bersama oleh audiens, entimem secara intuitif menyatukan pembicara dan audiens, dan memberi bukti yang terkuat. Audiens sendiri membantu mekonstruksi bukti yang diberikan (dalam Griffin, 1991).

(b) Ethos mengacu pada kredibilitas pembicara. Aristoteles melihat bahwa argument yang logis saja tidak cukup, pembicara harus terlihat kredibel. Dalam retorika, ia memperkenalkan tiga kualitas yang membangun kredibilitas sumber yang tinggi (dalam Griffin, 1991):

\section{(1) Perceived Intelligence}

Audiens menilai tingkat kepintaran dengan ketimpangan kepercayaan mereka dengan gagasan pembicara.

(2) Virtuous Character

Karakter berhubungan dengan citra pembicara sebagai seseorang yang baik dan jujur.

(3) Goodwill

Goodwill adalah penilaian positif dari niat pembicara terhadap audiens. Aristoteles menganggap bahwa seorang pembicara dapat memiliki kepintaran dan karakter yang bermutu dan ia belum dapat perhatian yang baik dari audiensnya. 
(c) Pathos bukan berarti memanfaatkan emosi destruktif audience, namun sebagai pengukuran korektif yang dapat membantu pembicata membangun ketertarikan emosional yang mampu menginspirasi pengambilan keputusan. (dalam Griffin, 1991).

(d) Five Canons of Rhetoric

Retorika berpusat pada 'The Five Canons of Rhetoric', yaitu invention, arrangement, style, delivery, dan memory. Dengan adanya perkembangan retorika, 'The Five Canons of Rhetoric' ini telah mengalami proses lanjutan tidak hanya berhenti sampai pidato, namun juga digunakan untuk mendeskripsikan berbagai jenis konstruksi simbolis (dalam Littlejohn \& Foss, 2011)

(1)Invention: Invention merujuk pada konseptualisasi, yaitu proses dimana kita menetapkan makna kepada simbol melalui interpretasi. (dalam Littlejohn \& Foss, 2011)

(2)Arrangement: Arrangement adalah proses menyusun simbolsimbol, menyusun informasi dengan memperhatikan hubungan dengan orang-orang, simbol, dan konteks yang terlibat (dalam Littlejohn \& Foss, 2011)

(3) Style: Style memperhatikan pertimbangan-pertimbangan di dalam presentasi simbol-simbol tersebut, mulai dari pemilihan sistem simbol, hingga arti yang kita berikan pada simbol-simbol tersebut, begitu pula perilaku simbolis mulai dari kata dan tindakan, hingga pakaian dan furnitur (dalam Littlejohn \& Foss, 2011)

(4)Delivery: Penyampaian yang natural bersifat persuasif, sedangkan yang artifisial sangat bertolakbelakang (dalam Griffin, 1991) Delivery telah menjadi perwujudan simbolsimbol dalam bentuk fisik, mencakup jangkauan pilihan dari nonverbal, lisan, tulisan, hingga pesan yang dimediasi (dalam Littlejohn \& Foss, 2011)

(5)Memory: retoris Roman merasa bahwa penekanan pada ingatan butuh dilakukan. Pada zaman modern, memory setara dengan latihan (dalam Griffin, 1991)

Teori selanjutnya yang digunakan adalah teori brand ambassador. Lea Greenwood menjelaskan ada empat manfaat utama dari penggunaan selebriti sebagai brand ambassador (dalam Aulia, 2018)

(1) Press coverage (liputan pers yang positif)

(2) Changing perception of brands (mengubah persepsi konsumen tentang merek)

(3) Attracting new customers (menarik konsumen baru)

(4) Freshening up an existing campaign (berbagai kegiatan kampanye ataupun promosi akan tetap efektif) 


\section{METODE}

Penelitian ini merupakan penelitian kualitatif dengan paradigm konstruktivisme. Paradigma merupakan cara pandang, kepercayaan, asumsi, konsep, proposisi, atau persepsi mengenai cara kerja penelitian yang bersifat naturalistik dengan pendekatan subjektif serta penilaian interpretif dan kontekstual (dalam Ibrahim, 2015). Dalam paradigma konstruktivisme, bahasa tidak lagi dilihat sebagai alat untuk memahami realitas objektif belaka dan dipisahkan dari subjek sebagai penyampai pesan. Paradigma ini juga menganggap subjek sebagai faktor sentral dalam kegiatan komunikasi dan hubungan-hubungan sosialnya.

Hal ini berarti, subjek memiliki kemampuan melakukan kontrol terhadap maksudmaksud tertentu dalam setiap wacana (dalam Ardianto \& Q-Anees, 2007)

Dalam penelitian ini yang menjadi subjek penelitian adalah Public Relations The Body Shop dan objek penelitian adalah The Body Shop Indonesia. Teknik pengumpulan data yang digunakan adalah dengan melakukan wawancara. Wawancara dilakukan dengan tiga jenis narasumber, yaitu:

(1) Informan kunci

Informan kunci dalam penelitian ini adalah Ibu Ratu Ommaya selaku Public Relations Manager The Body Shop Indonesia.

Informan ahli

Informan ahli dalam penelitian ini adalah Ma'am Elke Alexandrina yaitu Programme Director London School Academy.

Informan pendukung

Informan pendukung dalam penelitian ini adalah Dhiandra, Anggie, dan Satrio yang merupakan pengguna The Body Shop dan memiliki awareness terkait Cinta Laura yang menjadi brand ambassador The Body Shop Indonesia.

\section{HASIL PENELITIAN}

Dari penelitian ini dapat diperoleh bahwa komunikasi retorika yang dilakukan oleh Cinta Laura selaku brand ambassador dari The Body Shop Indonesia dan mengampanyekan kosmetik cruelty-free sudah mampu menggerakkan audiencenya. Meski begitu, public speaking yang ia lakukan masih terlihat terlalu dikontrol oleh pihak perusahaan. Dimana hal ini membuat Cinta terlihat lebih fokus pada promosi produk The Body Shop Indonesia dalam rangka meningkatkan penjualan, dan kurang menonjolkan kampanye itu sendiri.

Dalam teorinya, Aristoteles menyebutkan penggunaan analogi atau perumpamaan dalam komunikasi retorika. Bila dilihat dari komunikasi retorika yang dilakukan Cinta Laura, ia tidak menyampaikan bentuk analogi apapun. Namun, hal tersebut bukanlah yang membuat komunikasi retorikanya kurang meyakinkan. Hal ini berarti, ketiadaan penggunaan analogi dalam komunikasi retorika tidak memiliki pengaruh yang negatif terhadap respon audience.

Cinta Laura sendiri merupakan seorang public figure yang pernah berkuliah di Columbia University, Amerika Serikat dan lulus dan mendapatkan double degree. Hal ini membuat audience melihat Cinta Laura sebagai seorang yang cerdas dan dianggap kredibel menyampaikan kampanye ini. Padahal bila dikaitkan dengan ethos, Aristoteles tidak menyatakan perceived intelligence yang dimaksud adalah kecerdasan akademik. Namun, menurut audience ini lah yang membangun kredibilitas Cinta Laura.

Selain itu, Cinta Laura juga merupakan seorang pemerhati isu hak asasi manusia, lingkungan hidup, dan juga pecinta binatang. Tanpa publikasi dari media pun ia mau 
melakukan kegiatan yang mendukung isu-isu tersebut. Inilah yang membuatnya terlihat tulus atau sincere. Ini pula lah yang membuat audience melihatnya memiliki virtuous character. Dimana karakter yang disukai oleh audience bukan saja sifat yang baik, namun public figure tersebut juga harus menunjukkan values atau nilai-nilai yang ia pegang melalui aktivitas yang ia lakukan. Cinta Laura dilihat tidak hanya melakukan sesuatu untuk dirinya sendiri, naun juga untuk kelangsungan lingkungan hidup sekitarnya.

Cinta Laura sudah menjadi selebriti di Indonesia sejak akhir tahun 2007, dimana ia saat itu dikenal sebagai seorang pemain sinetron dengan darah campuran Jerman-Indonesia. Salah satu yang membuatnya khas adalah cara bicaranya yang kebule-bulean. Secara fisik, Cinta Laura memiliki penampilan seperti model papan atas, dan juga kepribadian yang rendah hati dan mudah berbaur. Ini lah yang menyebabkan Cinta Laura dianggap sebagai role model yang mampu menginspirasi audience dari generasi Y (milenial).

Namun, profil Cinta Laura yang merupakan seorang blasteran, berasal dari keluarga kelas atas, dan cantik bak model Internasional membuatnya memiliki gap yang terlalu jauh dengan audience di Indonesia. Hal ini berarti walaupun banyak yang mengidolakannya, mereka masih akan menganggap sesuatu hanya akan terlihat bagus karena di gunakan oleh Cinta Laura dan akan biasa saja ketika digunakan oleh mereka. Karena ini, audience kurang dapat merasa terhubung atau relate dengan Cinta Laura. Ini lah yang kemudian juga menjadi tantangan bagi sebuah merek untuk mencari dan memilih representatifnya.

Dalam konseptualisasi pesan komunikasi retorika, hal ini dilakukan oleh The Body Shop Indonesia. Selain memperhatikan data, perusahaan juga harus melihat kesiapan audience dalam menerima informasi yang akan disampaikan. Perusahaan harus mampu memprediksi bagaimana feedback yang akan didapatkan ketika pesan yang dibuat tersebut disampaikan kepada audience. Proses konseptualisasi pesan ini juga dipermudah karena Cinta Laura sudah memiliki awareness terkait isu yang dibawakan dalam kampanye kosmetik cruelty-free.

Dalam mempersiapkan komunikasi retorikanya, Cinta Laura melakukan pendekatan yang santai agar audience mampu dengan mudah memahami informasi yang ia sampaikan. Selain karena memang pembawaannya yang santai, Cinta juga berusaha menjangkau lebih banyak audience dengan pendekatan yang santai ini. Namun, kebiasaannya mencampurkan Bahasa Indonesia dan Bahasa Inggris dapat menimbulkan kesalahpahaman, apalagi dengan hadirnya audience yang umum dan tidak segmented.

Penyampaian pesan yang dilakukan oleh Cinta Laura dianggap masih kurang menonjolkan nilai-nilai cruelty-free yang dipegang oleh The Body Shop Indonesia. Padahal dengan pengetahuannya terkait isu tersebut, seharusnya Cinta mampu menonjolkan isu yang dibawakan lebih banyak lagi. Cinta Laura terlihat natural saat melakukan komunikasi retorika, namun ia masih terlihat dikontrol oleh The Body Shop Indonesia perihal pesan yang ia sampaikan, karena lebih fokus pada produk. Maka dapat diketahui bahwa cara penyampaian yang natural belum dapat menjamin bahwa komunikasi retorika yang dilakukan mampu meyakinkan audience yang hadir saat itu.

Meskipun bersifat positif, tidak banyak liputan pers yang beredar terkait peran Cinta Laura sebagai brand ambassador The Body Shop Indonesia. Maka dapat dikatakan bahwa Cinta Laura tidak sepenuhnya memberi manfaat ini kepada perusahaan. Cinta Laura juga tidak mampu mengubah persepsi audience tentang The Body Shop. Hal ini dikarenakan positioning merek ini yang sudah relatif kuat bahkan sebelum menggunakan Cinta Laura sebagai brand ambassador. Meskipun Cinta Laura dianggap kredibel menyampaikan 
kampanye ini, loyal customers dan juga beauty influencer dilihat lebih mampu mengadvokasi merek ini kepada orang-orang sekitarnya. Penyebabnya adalah gap antara mereka dengan audience tidak sebesar gap antara Cinta Laura dengan audience. Sehingga audience pun lebih relate dengan komunikator, mudah menerima pesan dan lebih yakin atas pesan yang disampaikan.

\section{SIMPULAN}

Dari penelitian ini dapat ditarik kesimpulan bahwa komunikasi retorika yang dilakukan oleh Cinta Laura sudah sesuai arahan yang diberikan oleh The Body Shop Indonesia. Cinta Laura yang sudah aware dengan isu ini pun menjadi kemudahan dalam melakukan konseptualisasi pesan dan dalam mengarahkan Cinta Laura. Meski begitu, Cinta Laura masih terlihat lebih fokus pada agenda The Body Shop Indonesia untuk meningkatkan product sales dibandingkan kampanye cruelty-free itu sendiri. Selain itu, jauhnya gap antara Cinta Laura dengan audience juga menyebabkan komunikasi retorika yang ia lakukan menjadi kurang meyakinkan audience. Selain itu, positioning The Body Shop yang sudah relatif kuat - bahkan sebelum menobatkan Cinta Laura sebagai brand ambassador membuat Cinta Laura tidak mampu mengubah persepsi audience terkait merek tersebut. Beauty influencer dan loyal customers dilihat lebih mampu meyakinkan audience, hal ini dikarenakan gap yang tidak terlalu jauh antara mereka dengan audience itu sendiri.

\section{DAFTAR PUSTAKA}

Ansellina, L. (2015). Pembentukan Brand Image Keds oleh Marketing Communication. Metrox Group.

Ardianto, E., \& Q-Anees, B. (2007). Filsafat Ilmu Komunikasi. Bandung: Simbiosa Rekatama Media.

Aulia, M. K. (2018). Pengaruh Brand Ambassador terhadap Brand Image pada Mamahke Jogja. e-Proceeding of Management : 5.2. p. 2569-2576.

Funk, T. (2013). Advanced Social Media Marketing: How To Lead, Launch, and Manage A Successful Social Media Program. California: Apress.

Griffin, E. A. (2012). a first look at communication theory. New York: McGraw-Hill. Ibrahim. (2015). Metodologi Penelitian Kualitatif: Panduan Penelitian Beserta Contoh Proposal Kualitatif. Bandung: Alfabeta.

Littlejohn, S. W., \& Foss, K. A. (2011). Theories of Human Communication. Long Grove: Waveland Press, Inc.

Meidiawati, R. T. (2015). Penerapan Komunikasi Persuasif di SMP Master Depok (studi kasus pada guru di SMP Master Depok). e-Proceeding of Management : Vol.2, No.3. P. 4116-4123 